\title{
Use of Cerium(IV) Nitrate in the Spectrophotometric Determination of Levodopa and Methyldopa in the Pure Form and Pharmaceutical Preparations
}

\author{
Murad I. H. Helaleh, Nafisur Rahman and Eyad S. M. Abu-Nameh \\ Analytical Research Division, Department of Chemistry, Aligarh Muslim University, Aligarh-202002, India
}

\begin{abstract}
An accurate and simple quantitative method for determining levodopa and methyldopa is proposed. Cerium(IV) has been successively used to react with drugs in $2 \mathrm{M} \mathrm{H}_{2} \mathrm{SO}_{4}$ at $80^{\circ} \mathrm{C}$. The absorbance of colored products was measured at 510 and $550 \mathrm{~nm}$ for levodopa and methyldopa, respectively. The method has been extended to the determination of these drugs in dosage forms. The results have been statistically compared with those obtained by the reference method.
\end{abstract}

Keywords Levodopa, methyldopa, spectrophotometry, cerium(IV) nitrate, pharmaceutical products analysis

Levodopa and methyldopa, having a phenolic or catechol functional group, usually serve to treat Parkinson's disease. Several methods have been cited in the literature for their determination. A great deal of interest has been given to the spectrophotometric determination..$^{1-8}$ On the other hand, some sporadic methods have been recorded other than spectrophotometry, such as US Pharmacopeia ${ }^{9}$, B.P. official method ${ }^{10}$, amperometric oxidation ${ }^{11}$ and high-performance liquid chromatography with electrochemical detection. ${ }^{12}$ From our viewpoint, most of the above-mentioned methods lack the simplicity needed for a routine analysis.

In the present method, $\mathrm{Ce}$ (IV) was reacted with drug samples in a sulfric acid medium at a temperature maintained at $80^{\circ} \mathrm{C}$ for $20-25 \mathrm{~min}$. The final product was determined at $510 \mathrm{~nm}$ and $550 \mathrm{~nm}$ for levodopa and methyldopa, respectively.

This work was motivated by an attempt to develop a simple, accurate and sensitive assay procedure for these drugs through the formation of complexes with $\mathrm{Ce}(\mathrm{IV})$.

\section{Experimental}

\section{Apparatus}

A Bausch and Lomb spectronic 20D ${ }^{+}$spectrophotometer was used for all absorbance measurements, with 1$\mathrm{cm}$ cells, and a temperature-controlled water bath (NSW133).

\section{Reagents and samples}

High-purity distilled water was used throughout. All of the chemicals and reagents were of analytical reagent or pharmaceutical grade.

Stock solutions of $2.5 \mathrm{mg} / \mathrm{ml}$ and $5 \mathrm{mg} / \mathrm{ml}$ for methyldopa and levodopa in the pure form were prepared by dissolving exactly $250 \mathrm{mg}$ and $500 \mathrm{mg}$ in $100 \mathrm{ml}$ of water each in a calibrated flask. The absolute purity of these materials was checked by the 1,10phenanthroline method ${ }^{13}$ and found to be $99.90 \%$ and 99.98\% for levodopa and methyldopa, respectively. Stock solutions of the drugs should be stored in a wellclosed vessels, and direct contact with light should be avoided. They should also be freshly prepared.

\section{Determination of levodopa and methyldopa in tablets}

Five tablets were weighed and ground into a fine powder. Masses of powder containing $500 \mathrm{mg}$ of levodopa and $250 \mathrm{mg}$ of methyldopa were accurately mixed with water, and then filtered through Whatman No. 1 filter paper. After washing, the filtrate was made to $100 \mathrm{ml}$ with water in a calibrated flask.

Cerium(IV) solution (Loba Chemie, India). A stock solution of $\left(\mathrm{NH}_{4}\right)_{2} \mathrm{Ce}\left(\mathrm{NO}_{3}\right)_{6}(0.01 \mathrm{M})$ was prepared in $2 \mathrm{M}$ sulfuric acid.

[Procedure A (Levodopa)]

After $5.0 \mathrm{ml}$ of cerium(IV) nitrate solution was placed in a $10 \mathrm{ml}$ calibrated flask, $0.4-1.1 \mathrm{ml}$ of a levodopa solution was added. The mixture was placed on a water bath at a temperature maintained at $80^{\circ} \mathrm{C}$ and swirled for 20-25 min. Thereafter, it was cooled under tap and then diluted upto the mark with water. The colored product was determined at $510 \mathrm{~nm}$ against a reagent blank omitting the drug sample.

[Procedure B (methyldopa)]

To a known volume of methyldopa $(0.5-1.0 \mathrm{ml})$, $3.5 \mathrm{ml}$ of $\mathrm{Ce}(\mathrm{IV})$ solution was added. The procedure for levodopa was repeated, except that the colored product obtained in this case was determined at $550 \mathrm{~nm}$. 


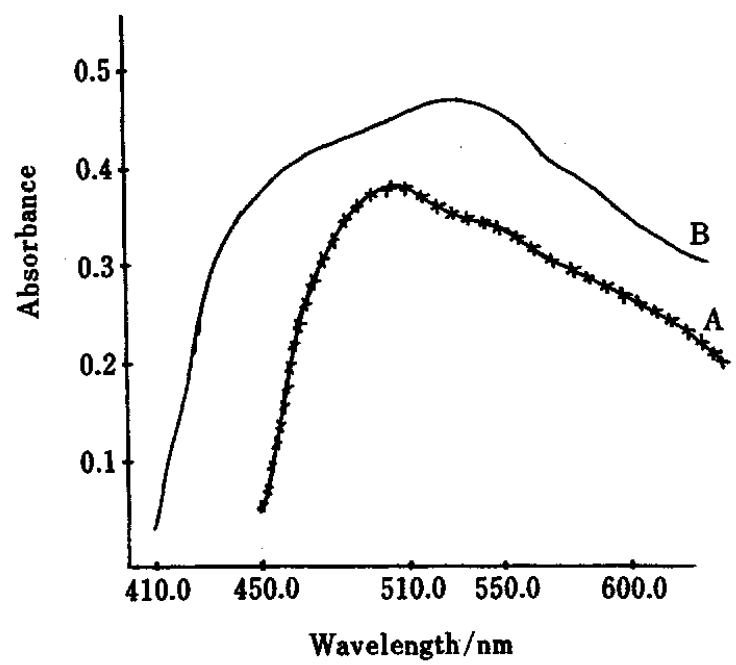

Fig. 1 Absorption spectra of the reaction complex: A, levodopa $(35 \mu \mathrm{g} / \mathrm{ml})-\mathrm{Ce}(\mathrm{IV}) ; \mathrm{B}$, methyldopa $(20 \mu \mathrm{g} / \mathrm{ml})$ $\mathrm{Ce}(\mathrm{IV})$; heated for $25 \mathrm{~min}$ at $80^{\circ} \mathrm{C}$ in $2 \mathrm{M}$ sulfuric acid.

\section{Results and Discussion}

In this method, $\mathrm{Ce}$ (IV) in sulfuric acid is used to react with levodopa and methyldopa. It was observed that the reaction was dependent on the concentration of sulfuric acid, and that the reaction takes place only at the acid concentration range from $2 \mathrm{M}$ to $12 \mathrm{M}$. The reaction rate is dependent on these factors. Thus, the optimum conditions were established by varying some parameters, including the acid concentration, temparature and heating time. The reaction is slow, but can be accelerated by increasing the acid concentration and heating time. It was found that $80^{\circ} \mathrm{C}$ is suitable for studying the complex products of levodopa and methyldopa. The absorbance also increases with higer acidity and time, and it reaches a maximum after $15 \mathrm{~min}$. However, at high temperature (above $80^{\circ} \mathrm{C}$ ) there is a risk of unwanted chemical changes when the reaction mixture becomes slightly turbid, and causes a hinderance in the determination.

\section{Analytical data}

Beer's law was found to be valid over the concentration range between $200-550 \mu \mathrm{g} \mathrm{ml}^{-1}$ and $125-250 \mu \mathrm{g} \mathrm{ml}^{-1}$, with a molar absorptivity of $1.08 \times 10^{3}$ and $1.15 \times 10^{3}$ $1 \mathrm{~mol}^{-1} \mathrm{~cm}^{-1}$ for levodopa and methyldopa, respectively. The absorption spectra for the reaction of $\mathrm{Ce}(\mathrm{IV})$ nitrate with levodopa and methyldopa are shown in Fig. 1.

\section{Molar ratio stoichiometry}

In order to establish the molar ratio between the drugs and the reagent used, the continuons variation method (Figs. 2 and 3) has been applied, which indicates that $1: 2$ ratio of levodopa to $\mathrm{Ce}(\mathrm{IV})$ and a ratio of $1: 3$ for methyldopa and $\mathrm{Ce}(\mathrm{IV})$, with stability constants $\left(K_{\mathrm{f}}\right)$ of $0.48 \times 10^{9}$ and $1.2 \times 10^{12}$ for levodopa and methyldopa

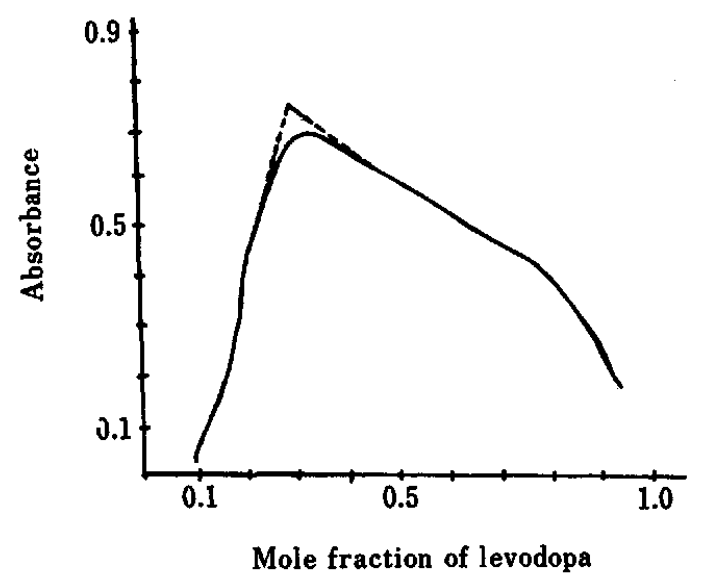

Fig. 2 Job plot for levodopa-Ce(IV) complex in $2 \mathrm{M} \mathrm{H}_{2} \mathrm{SO}_{4}$ at $510 \mathrm{~nm}: 0.325 \mathrm{~mol}$ fraction of levodopa shows the maximum absorption. Therefore, the ratio of drug to reagent is $1: 2$.

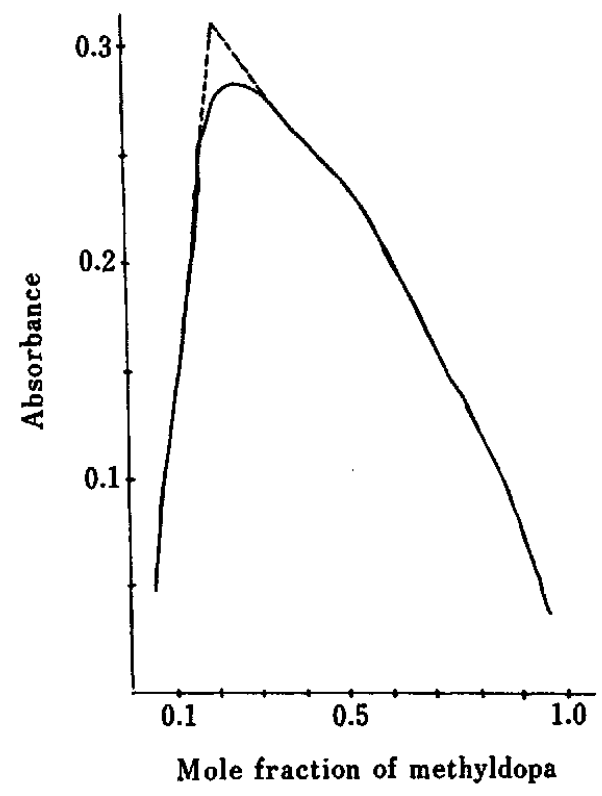

Fig. 3 Job plot for the methyldopa-Ce(IV) complex in $2 \mathrm{M}$ $\mathrm{H}_{2} \mathrm{SO}_{4}$ at $550 \mathrm{~nm}: 0.25 \mathrm{~mol}$ fraction of methyldopa shows the maximum absorption. Therefore, the ratio of drug to reagent is $1: 3$.

respectively, which indicate the stability of complex formation. The stability constants ware calculated by

$$
K_{\mathrm{f}}=\frac{C\left(1-\alpha^{-}\right)}{\left(C \alpha^{-}\right)\left(b C \alpha^{-}\right)^{b}},
$$

where, $\alpha^{-}=$degree of dissociation, $C=$ molar concentration, $b=$ number of molecules of the reagent.

In order to determine the molar ratio for levodopa and methyldopa, reagent solutions were added in $25 \mathrm{ml}$ and $50 \mathrm{ml}$ volumetric flasks for levodopa and methyldopa, respectively, as shown below and the volume made 
Table 1 Test on the precision and accuracy of the determination of levodopa in the pure form by the proposed method

\begin{tabular}{cclcccc}
\hline $\begin{array}{c}\text { Sample } \\
\text { No. }\end{array}$ & $\begin{array}{c}\text { Amount taken/ } \\
\mu \mathrm{g} \mathrm{ml}^{-1}\end{array}$ & $\begin{array}{c}\text { Amount found } \\
\mu \mathrm{g} \mathrm{ml}^{-1}\end{array}$ & SD & RSD & \%Error & \%Recovery \\
\hline 1 & 30.0 & $30.00,30.00,30.13$, & 0.09 & 0.3 & 0.00 & 100.0 \\
2 & 40.0 & $\begin{array}{l}29.88,30.00 \\
39.93,40.00,39.93,\end{array}$ & 0.04 & 0.1 & -0.10 & 99.9 \\
3 & 55.0 & $50.00,39.93$ & & & 99.9 \\
& & $55.00,54.98,55.00$, & 0.03 & 0.06 & -0.04 & \\
\hline
\end{tabular}

Table 2 Test on the reproducibility of the proposed method for the determination of levodopa in tablets

\begin{tabular}{cclcccc}
\hline $\begin{array}{c}\text { Sample } \\
\text { No. }\end{array}$ & $\begin{array}{c}\text { Amount taken/ } \\
\mu \mathrm{g} \mathrm{ml}^{-1}\end{array}$ & $\begin{array}{c}\text { Amount found } \\
\mu \mathrm{g} \mathrm{ml}^{-1}\end{array}$ & SD & RSD & \%Error & \%Recovery \\
\hline 1 & 25.0 & $24.88,24.93,25.75$, & 0.36 & 1.44 & +0.4 & 100.4 \\
& 35.0 & $\begin{array}{l}25.00,25.00 \\
25.00,34.98,34.88,\end{array}$ & 0.05 & 0.15 & -0.1 & 99.9 \\
& $35.00,35.00$ & & & 100.2 \\
& 50.0 & $50.00,50.75,50.00$, & 0.38 & 0.76 & +0.2 & \\
\hline
\end{tabular}

Table 3 Test on the reproducibility of the proposed method for the determination of methyldopa in tablets

\begin{tabular}{|c|c|c|c|c|c|c|}
\hline $\begin{array}{c}\text { Sample } \\
\text { No. }\end{array}$ & $\begin{array}{c}\text { Amount taken/ } \\
\mu \mathrm{g} \mathrm{ml}^{-1}\end{array}$ & $\begin{array}{l}\text { Amount found/ } \\
\mu \mathrm{g} \mathrm{ml}^{-1}\end{array}$ & SD & RSD & $\%$ Error & $\%$ Recovery \\
\hline 1 & 12.5 & $\begin{array}{l}12.50,12.38,12.50 \\
12.50,12.50\end{array}$ & 0.56 & 0.45 & -0.2 & 99.8 \\
\hline 2 & 17.5 & $\begin{array}{l}17.50,17.44,17.55 \\
17.50,17.50\end{array}$ & 0.26 & 0.15 & -0.06 & 99.9 \\
\hline 3 & 22.5 & $\begin{array}{l}22.44,22.50,22.50 \\
22.50,22.50\end{array}$ & 0.27 & 0.12 & -0.3 & 99.7 \\
\hline
\end{tabular}

up to the mark with distilled water.

\begin{tabular}{rlllll} 
& & \multicolumn{2}{c}{$\begin{array}{c}\text { Volume of drug } \\
\text { soln./ml }\end{array}$} & & \multicolumn{2}{c}{$\begin{array}{c}\text { Volume of Ce(IV) } \\
\text { soln./ml }\end{array}$} \\
\cline { 2 - 3 } \cline { 5 - 6 } & LD & MD & & LD & MD \\
& 0.5 & 0.5 & & 9.5 & 4.5 \\
2 & 1.0 & 1.0 & & 9.0 & 4.0 \\
3 & 2.0 & 1.25 & & 8.0 & 3.75 \\
4 & 3.0 & 1.5 & & 7.0 & 3.5 \\
5 & 3.25 & 2.0 & & 6.75 & 3.0 \\
6 & 4.0 & 2.3 & & 6.0 & 2.7 \\
7 & 5.0 & 2.5 & & 5.0 & 2.5 \\
8 & 6.0 & 3.0 & & 4.0 & 2.0 \\
9 & 6.5 & 3.5 & & 3.5 & 1.5 \\
10 & 7.0 & 4.0 & & 3.0 & 1.0 \\
11 & 8.0 & 4.5 & & 2.0 & 0.5
\end{tabular}

The molar concentration of levodopa is $0.025 \mathrm{M}$ and of methyldopa is $0.012 \mathrm{M}$.

The molar concentration of $\mathrm{Ce}(\mathrm{IV})$ is $0.025 \mathrm{M}$.

\section{Precision}

The precision and accuracy of the proposed method and its reproducibility were checked using the pure form of drugs and tablets. The results are listed in Tables 1,2 and 3. Therefore, the results promote sufficient accuracy to the proposed method.

\section{Interference}

The determinations of levodopa and methyldopa were successfully extended in the presence of common excipients, which are usually added to the dosage forms during their preparation, such as lactone, fructose, sucrose, glucose and starch. These excipients do not cause any interference in the determination, where a procentual change in the measured absorbance values of levodopa and methyldopa was used to determine the interferences.

\section{Application of the proposed method}

The method was applied to the determination of levodopa and methyldopa in a number of dosage forms. 
Table 4 Results for the determination of levodopa and methyldopa in pharmaceutical preparations by the proposed method

\begin{tabular}{cccc}
\hline $\begin{array}{c}\text { Drug } \\
\text { (Supplier) }\end{array}$ & $\begin{array}{c}\text { Nominal } \\
\text { composition/mg }\end{array}$ & $\begin{array}{c}\text { Found/ } \\
\mathrm{mg}\end{array}$ & Error, \% \\
\hline $\begin{array}{c}\text { Levopa (tab.) } \\
\text { (Wallace) }\end{array}$ & 500 levodopa & 502.25 & +0.45 \\
$\begin{array}{c}\text { Emdopa (tab.) } \\
\text { (IDPL) }\end{array}$ & 250 methyldopa & 249.8 & -0.08 \\
\hline
\end{tabular}

Mean of 8 determinations; error calculated to nominal content.

The obtained results are summarized in Table 4. The results were also compared with those obtained by the reference method ${ }^{13}$, and are given in Table 5 .

The calculated t-values did not exceed the theoretical values at the $95 \%$ confidence level, showing the absence of any significant difference between the two methods. It is also mentioned that this new method is reproducible, simple, accurate, and suitable for routine analysis.

\section{References}

1. P. Sharma and K. Srinivasulu, Indian J. Chem. Soc., 68, 374 (1991).

2. P. B. Issopoulos, Pharm. Acta Helv., 64, 82 (1989).
Table 5 Determination of levodopa and methyldopa by the proposed method in contrast with the reference method ${ }^{13}$

\begin{tabular}{cccc}
\hline Drug & Proposed method & 1,10 -phen. method & $t$ \\
\hline $\begin{array}{c}\text { Levopa } \\
\text { (Wallace) }\end{array}$ & $100.45 \pm 0.87$ & $99.96 \pm 0.77$ & 1.5 \\
Emdopa & $99.92 \pm 2.7$ & $100.17 \pm 0.38$ & 1.7 \\
\hline
\end{tabular}

Data presented as mean \pm SD for 8 determinations. $t$, theoretical value $=2.365$.

3. M. E. El-Kommos, Bull. Pharm. Sci. Assuit Univ., 10, 34 (1987).

4. S. Sherry and E. J. Behrman, Anal. Lett., 21, 183 (1988).

5. R. T. Sane, G. J. Bhoun and S. V. Sawant, Indian Drugs, 24, 207 (1987).

6. G. R. Rao and A. B. Avadhanulu, Indian Drugs, 23, 699 (1986).

7. A. Berween, K. D. Khalaf and G. M. Dela, Talanta, 42, 627 (1995).

8. K. Nikolic and M. Medenica, Farmaco, 45, 1037 (1990).

9. U. S. Pharmacopoeia, XXII, 756, 865 (1980).

10. British Pharmacopeia, H. M. Stationary, 245 (1980).

11. P. T. Kissinger Anal. Chem., 49, 447A (1977).

12. M. A. Rihbany and F. D. Michael, J. Chromatogr., 248, 125 (1982).

13. P. B. Issopoulos, Fresenius' J. Anal. Chem., 336, 124 (1990).

(Received December 2, 1996) (Accepted May 29, 1997) 